\title{
Feasibility study and numerical simulation to design the steam flooding pilot test patterns
}

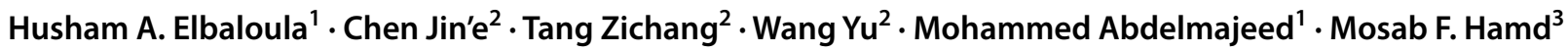

Received: 3 February 2020 / Accepted: 7 April 2020 / Published online: 11 May 2020

(c) The Author(s) 2020

\begin{abstract}
Steam flooding is a method of injecting steam to heat the oil and decrease its viscosity so that it will be easy to flow from injector to producer. Fula North East oil field is a massive edge and bottom water reservoir with good properties and high viscosity of crude oil. As of March 2018, the oil field has been fully commissioned in steam stimulation for 3 years and the water cut rises rapidly and the oil rate declines seriously. In this paper, through comprehensive analysis of the geological properties of reservoir, production dynamics of single well and cement quality of wellbore, the steam flooding pilot test area under different well groups is screened out. Advanced thermal enhanced oil recovery simulator has been used to build the model of 279, 888 cells to design and optimize steam flooding pilot area for this field. The best well space and development program are optimized; this paper supplies a theoretical foundation for the next step of steam flooding in the whole field. The results show that the optimum steam flooding parameters for this area are steam injection temperature of $270{ }^{\circ} \mathrm{C}$, with 5-7 MPa injection pressure, steam injection quality of more than 0.6 and steam injection rate of $1.6 \mathrm{~m}^{3} / \mathrm{day} / \mathrm{ha} / \mathrm{m}$, and the final recovery ratio will reach $32.3 \%$.
\end{abstract}

Keywords Numerical simulation $\cdot$ Thermal EOR $\cdot$ Steam flooding Sudanese oil fields

$\begin{array}{ll}\text { List of symbols } \\ \% & \text { Percentage } \\ \text { AG } & \text { Abu Ghabra } \\ \text { B1a } & \text { Bentiu 1a } \\ \text { B1a }+ \text { b } & \text { Bentiu 1a + Bentiu 1b } \\ \text { Bbl } & \text { Barrel } \\ \text { Bb1/day } & \text { Barrel per day } \\ \text { cP } & \text { Centipoise } \\ \text { CAPEX } & \text { Capital cost } \\ \text { CSS } & \text { Cyclic steam stimulation } \\ \text { Cum. } & \text { Cumulative } \\ \text { DNC } & \text { Do-nothing case } \\ \text { DX } & \text { Dimension in } X \text {-direction } \\ \text { DY } & \text { Dimension in } Y \text {-direction } \\ \text { DZ } & \text { Dimension in Z-direction } \\ \text { E\&P } & \text { Exploration and production }\end{array}$

Husham A. Elbaloula

hushamali66@gmail.com

Perto-Energy E\&P Co. Ltd, Khartoum, Sudan

2 Geophysical Research Institute, BGP, CNPC, Zhuozhou, China

3 Ministry of Petroleum \& Mining - OEPA, Khartoum, Sudan

$\begin{array}{ll}\text { EA } & \text { Areal sweep efficiency } \\ \text { ED } & \text { Displacement efficiency } \\ \text { EOR } & \text { Enhanced oil recovery } \\ \text { EV } & \text { Vertical sweep efficiency } \\ \text { FNE } & \text { Fula North East } \\ \text { IRR } & \text { Internal rate of return } \\ \mathrm{kJ} / \mathrm{kg} & \text { Kilojoule per kilogram } \\ \mathrm{M}^{3} & \text { Cubic meter } \\ \mathrm{m}^{3} / \mathrm{day} \mathrm{m} & \text { Cubic meter per day per meter } \\ \mathrm{m}^{3} / \mathrm{day} & \text { Cubic meter/day } \\ \mathrm{m} 3 / \mathrm{day} / \mathrm{ha} / \mathrm{m} & \text { Cubic meter per day per hectare per meter } \\ \mathrm{Max} & \text { Maximum } \\ \mathrm{mD} & \text { Meli Darcy } \\ \mathrm{Min} & \text { Minimum } \\ \mathrm{MM} \$ & \text { Million dollars } \\ \mathrm{MMm}{ }^{3} & \text { Million cubic meter } \\ \mathrm{MMSTB} & \text { Million stock tank barrel } \\ \mathrm{MOPM} & \text { Ministry of Petroleum and Mining } \\ \mathrm{MPa} & \text { Megapascal } \\ \mathrm{NP} & \text { Cumulative oil produced } \\ \mathrm{NPV} & \text { Net present value } \\ \mathrm{NS} & \text { Initial oil in place at the start of the flood } \\ { }^{\circ} \mathrm{C} & \text { Degree Celsius } \\ \mathrm{OEPA} & \text { Oil Exploration and Production Authority } \\ & \end{array}$




$\begin{array}{ll}\text { OPEX } & \text { Operating cost } \\ \text { OSR } & \text { Oil-steam ratio } \\ \text { PE } & \text { Petro-energy } \\ \text { Pi } & \text { Initial pressure } \\ \text { Pro. } & \text { Production } \\ \text { Psi } & \text { Pound-force per square inch } \\ \text { RF } & \text { Recovery factor } \\ \text { SF } & \text { Steam flooding } \\ \text { SF\#2 } & \text { Steam flooding phase number two } \\ \text { SPE } & \text { Society of Petroleum Engineering } \\ \text { STB } & \text { Stock tank barrel } \\ \text { US } & \text { United States } \\ \text { WIT } & \text { Water injection total }\end{array}$

\section{Introduction}

Thermal enhanced oil recovery (TEOR) is a family of tertiary processes defined as "any process in which heat is introduced intentionally into a subsurface accumulation of organic compounds for the purpose of recovering fuels through well."

Thermal methods of EOR entail the application of heat to the oil well. Thermal methods have been tested since 1950s, and they are the most advanced among EOR methods, as far as field experience and technology are concerned. They are best suited for heavy oils (10-20 API) and tar sands $\left(\leq 10^{\circ}\right.$ API). They have the ability to lower the viscosity of the oil and thus increase the mobility ratio. These methods are typically employed in relatively shallow oil wells with higher viscosity such as tar sands and heavy oil. Thermal methods of EOR have been highly successful in the USA, Canada, Venezuela and Indonesia and have also been used in China and Brazil. Within the USA, thermal methods account for around $40 \%$ of EOR production (Prats 1982).

\section{Types of thermal EOR}

- Steam flooding.

- Cyclic steam stimulation (CSS).

- Steam-assisted gravity drainage (SAGD).

- In situ combustion (ISC).

- Solar EOR.

- Electro-EOR (EEOR).

- Heated annulus steam drive (HASD).

- Steam and solvent processes.

FNE field is located about $9 \mathrm{~km}$ away from the North East of Fula field in Fula Sub-basin in Sudan; it is structurally subdivided into three main blocks, which are FNE-1, FNE-3 and FNE-N. There are three proved hydrocarbon-bearing formations (Aradaiba, Bentiu and AG), among which Bentiu is the main pay zone. Figure 1 shows the location of FNE.

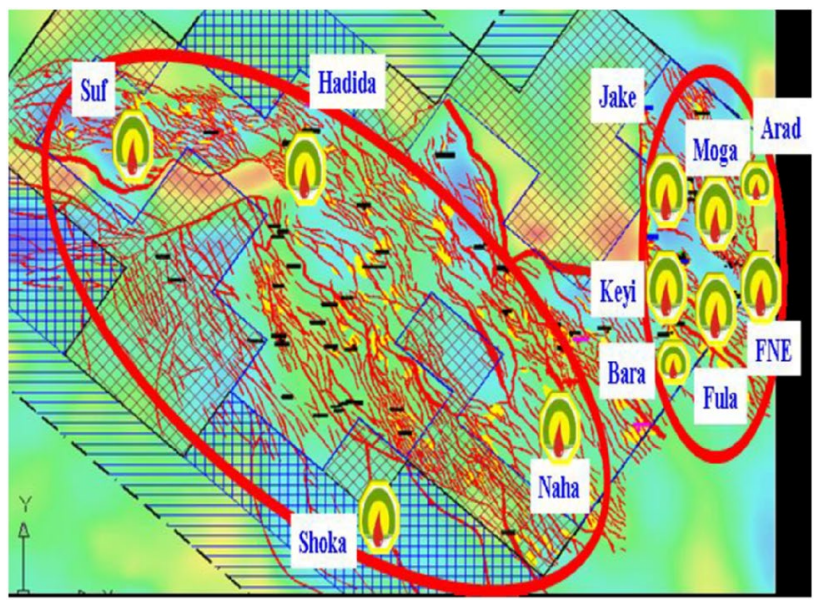

Fig. 1 FNE location map (Elbaloula et al. 2016)

FNE oil field is considered as heavy oil field and it has shallow reservoir, and Bentiu reservoir is affected by strong bottom water. The reservoir of FNE oil field is characterized by normal temperature and pressure system at $529 \mathrm{~m}$ depth. The average pressure is $576 \mathrm{psi}$ and the average temperature is $43.9{ }^{\circ} \mathrm{C}$. FNE has conventional heavy oil in both Aradaiba and Bentiu, and Bentiu reservoir has a relatively good quality with porosity ranging from 17 to $40 \%$, permeability ranging from 100 to $11000 \mathrm{mD}$ and viscosity of about 840 cP (Elbaloula et al. 2016).

The oil field put into production in 2010 with cold production and cyclic steam stimulation. By March 2018, a total of 117 wells had been drilled, including one horizontal well; 116 wells have been put into operation, of which 21 wells are producing as cold, 82 wells for steam stimulation and 13 wells for steam flooding. One hundred and eleven wells were opened with a daily oil production of $4896 \mathrm{bbl}$, a daily fluid production of $10,145 \mathrm{bbl}$, water cut of $54 \%$, the total original oil in place of 332MM STB, and the up-to-date recovery factor of reservoirs of $0.8 \%$.

\section{Literature review and screening}

Years of production shows that the daily oil production for steam stimulation is almost three times of the cold wells, indicating that injection steam into well bottom can heat the reservoir and reduce viscosity of the heavy oil to increase production capacity. Currently, the oil fields used for steam flooding include China's Liaohe oil field, US Kern River oil field, Indonesian Dori oil field and so on (Jones et al. 1995).

From screening, the Qi 40 of Liaohe oil field which put into steam flooding has been selected early as a reference example to illustrate the feasibility of steam flooding in FNE oil field. Qi 40 reservoir was put into operation in 1983 by steam stimulation with oil take-off rate of $15.3 \%$. During 
Table 1 Reservoir properties of each oil field using steam flooding (Elbaloula et al. 2016; Pearce and Megginson 1991; Jones et al. 1995; Taber et al. 1997)

\begin{tabular}{|c|c|c|c|c|c|c|c|}
\hline Item & Qi 40 & Shu175 & Wa 38 & Cruse E & $\begin{array}{l}\text { Kern } \\
\text { River }\end{array}$ & FNE & SPE (Taber) \\
\hline Reservoir type & $\begin{array}{l}\text { Tectonic-lithology } \\
\text { with edge-bottom } \\
\text { water }\end{array}$ & $\begin{array}{l}\text { Tectonic-lithology } \\
\text { with edge-bottom } \\
\text { water }\end{array}$ & $\begin{array}{l}\text { Sand with } \\
\text { good con- } \\
\text { nectivity }\end{array}$ & $\begin{array}{l}\text { Sand with } \\
\text { good con- } \\
\text { nectivity }\end{array}$ & Sand & $\begin{array}{l}\text { Tectonic-lithol- } \\
\text { ogy with bottom } \\
\text { water }\end{array}$ & \\
\hline Depth (m) & $625-1025$ & & $1240-1430$ & 548 & & 543 & $<1524$ \\
\hline Net pay $(m)$ & 37.7 & 47.8 & 21.5 & 36.6 & 29.5 & 44 & $>6$ \\
\hline $\mathrm{Pi}(\mathrm{psi})$ & 1232.5 & 1508 & $435-580$ & & & 564 & \\
\hline$T\left({ }^{\circ} \mathrm{C}\right)$ & 36.8 & 55 & & & & 44 & \\
\hline Porosity (\%) & 31.5 & 25.6 & 22.3 & & & 32 & \\
\hline Permeability (mD) & 2062 & 1500 & 1066 & & & 3200 & $>200$ \\
\hline $\begin{array}{l}\text { Viscosity@50 }{ }^{\circ} \mathrm{C} \\
\text { (mPa s }\end{array}$ & $3100-4600$ & 10,000 & 15,000 & & & $712-2543$ & $<100,000$ \\
\hline Well pattern & Anti-9 & & Anti-9 & Anti-5 & Anti-9 & Anti-5 & \\
\hline $\begin{array}{l}\text { SF period recovery } \\
(\%)\end{array}$ & $20.9-37.4$ & 23.4 & & & 37 & Study $>20$ & \\
\hline
\end{tabular}

the period of 1990-2000, the steam flooding test was carried out. In 2001, intermittent steam flooding was officially started. The well pattern was anti-9 spot with well space of 100 meters. As of December 2003, the oil take-off rate increased to $41.4 \%$, highlighting the superiority of steam flooding for heavy oil reservoirs (Jiu-quan et al. 2006).

By comparing the reservoir properties for each oil field and the applicability of steam flooding and comparing SPE table for EOR screening (Taber et al. 1997), as given in Table 1, it is considered that the Sudan FNE oil field is suitable for steam flooding, and this paper well covers the steam flooding screening, pilot area selection, pilot simulation and designing as well as optimization.

\section{Methodology}

The geological data, reservoir data and production data for FNE oil field have been collected and used for analysis to identify the situation of the field, and it is suitable for conducting steam injection and full-field implementation.

Advanced thermal EOR simulator software has been used to build the dynamic model and to design and optimize steam flooding injection and production parameters for FNE oil field.

The steps in Fig. 2) are used in this paper.

\section{Results and discussion}

The thermal recovery is essential for this field, and the first pilot has been conducted in FNE-16 well and the results showed that the CSS has the ability to double the production,

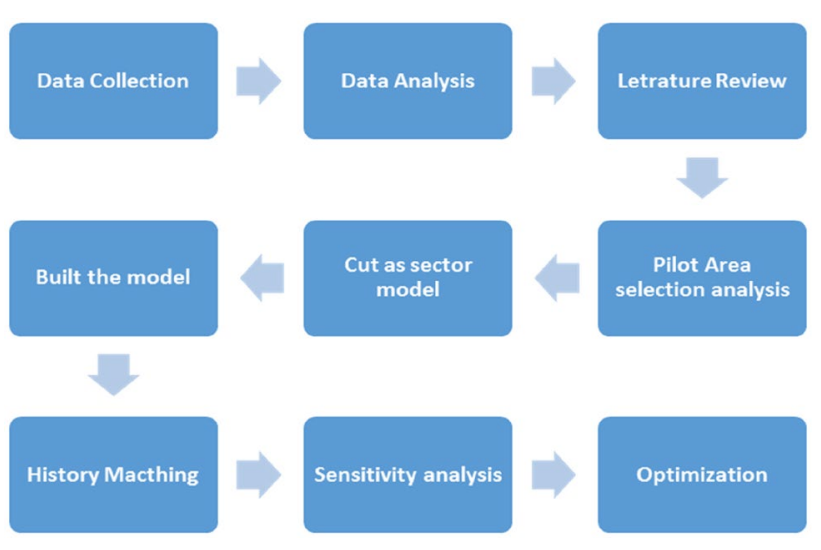

Fig. 2 The steps and workflow for this study

and then, additional wells have been added at each phase. Up to 2016, the total CSS wells are 67 including 37 wells are under the first and second cycles, 24 wells under the third and fourth cycles and 6 wells under the fifth cycle.

The average daily oil production for this field has been increased from $5300 \mathrm{bbl} . /$ day as of December 2014 to 8300 bbl./day as of September, 2016, and the peak oil production has been recorded in 2016 as 9000 bbl./day. The CSS is very successful, and the average oil rate is almost 1.6 times compared to cold production. The CSS only can increase the recovery percent from 32.5 to $34.2 \%$, which makes it more attractive as development scenario for FNE oil field (Elbaloula 2017).

The steam flooding pilot has been implemented in September 2015, and the results encourage to go for the second steam flooding pilot in this field in order to get full picture of full-field implementation as given in Table 2.

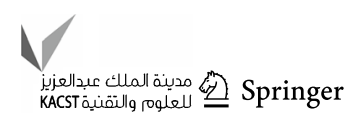


Table 2 Screening criteria for thermal recovery and development (Elbaloula et al. 2016)

\begin{tabular}{llll}
\hline Item & CSS & SF & FNE \\
\hline Pay depth (m) & $<1700$ & $<1300$ & 550 \\
Pay thickness (m) & $10-35$ & $7-60$ & 30 \\
NTG & 0.35 & $>0.4$ & 0.6 \\
Horizontal perm. (md) & $>200$ & $>200$ & 4000 \\
Porosity \% & $>20$ & $>20$ & 32 \\
Oil saturation \% & $>60$ & $>45$ & 70 \\
Dead oil viscosity, mPa s & $/$ & $<10,000$ & $661\left(50^{\circ}\right)$ \\
Reservoir pres (Psi) & $<1885$ & $<725$ & 610 \\
\hline
\end{tabular}

\section{Pilot area selection analysis}

In order to select the best location for pilot, screening of FNE oil field with steam flooding has been conducted; the following factors are considered:-

1. The pilot area must have abundant reservoir resources, and then, the properties can represent the general level of the whole oil field.

2. The sand body between the producer and the injector must have good connectivity and a uniform oil-water contact, and the interlayer should be fully considered to make sure that the injected steam plays a more desirable role.

3. At present, the daily oil production of some wells is in a decreasing stage, and the water cut is relatively high.
Dynamic analysis needs to be conducted to assist optimization.

4. The producers have experienced at least one cycle of high-temperature steam injection and soaking, and even four-six cycles. The cementing facility of some wells becomes damaged. Therefore, it is necessary to check the well cementing and propose workover before steam flooding.

Block 1 is located at a high structure with 16 wells, including 2 cold wells and 14 steam simulation wells. Two cold wells and three CSS wells were put into production in 2010 and 11 steam simulation wells in 2015. The main perforation layers are B1a and B1b. Block 2 is located in a relatively low structure with 11 wells, including three cold wells commissioned in 2010 and eight steam wells commissioned in 2015.

According to above screening principle and considering the block structure, the effective thickness of the reservoir (Fig. 3), the cementing quality and the current production status, the selected block 1 is selected as the steam flooding pilot area to carry out the next numerical simulation and development plan prediction.

\section{Building the numerical model}

Advanced thermal process reservoir simulator has been used which includes options such as chemical/polymer flooding, thermal applications, steam injection, horizontal wells, dual
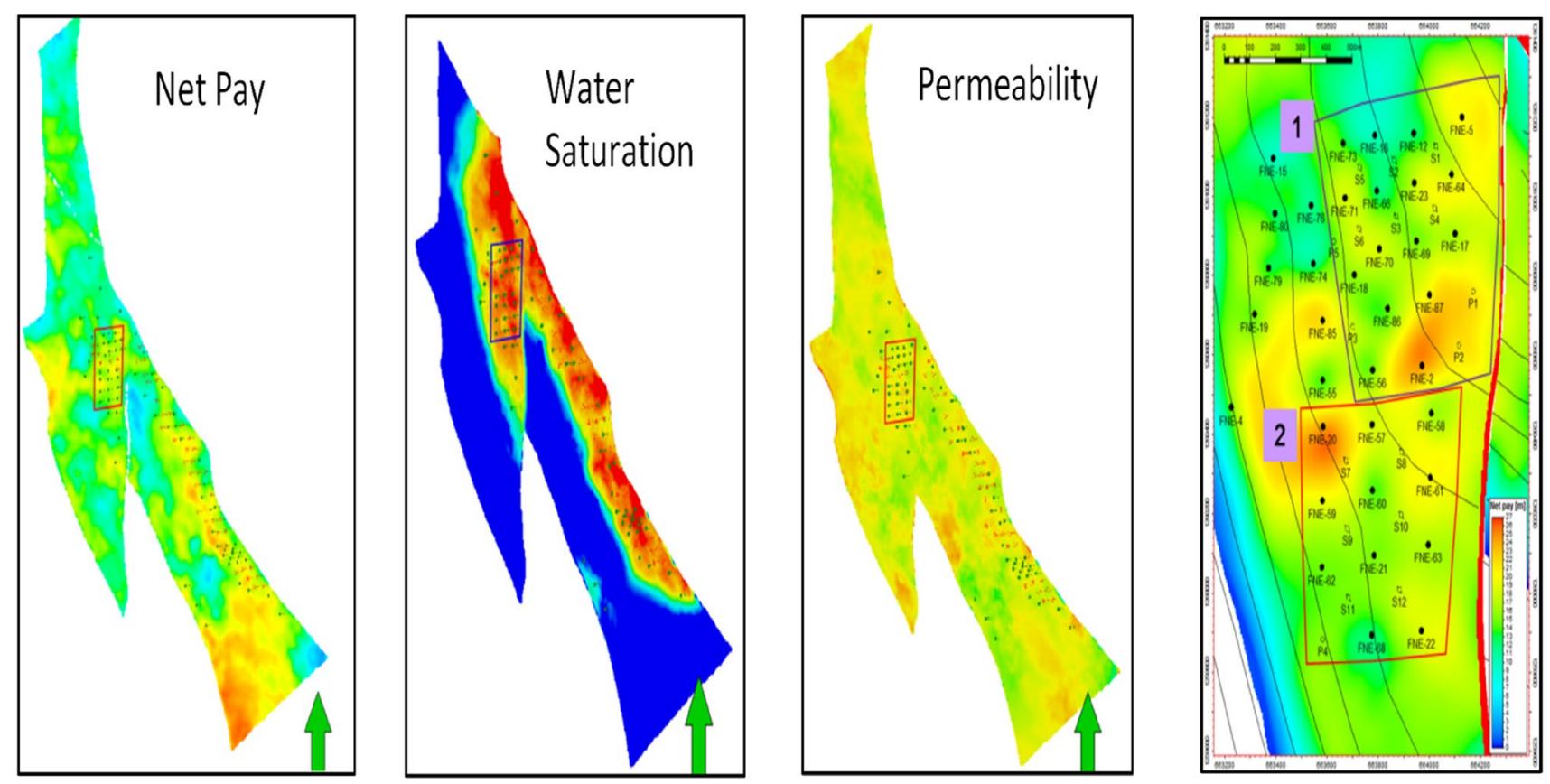

Fig. 3 Reservoir properties and pilot area

年

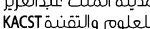
Springer 
Fig. 4 3D view of porosity distribution and wells location in FNE oil field

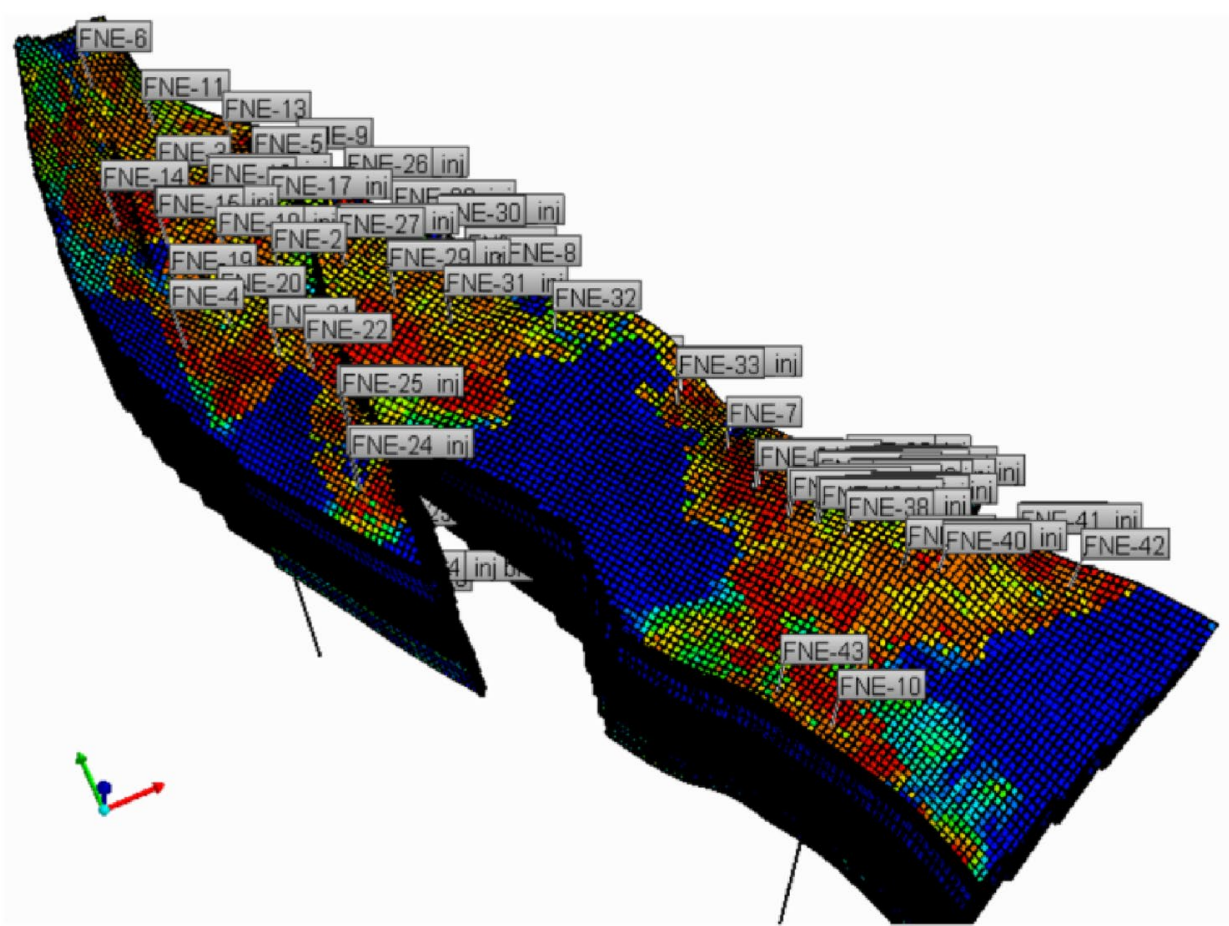

\section{Scenarios design for pilot test well group}

Essentially four types of well arrangements are used in fluid injection projects:

1. Irregular injection patterns.

2. Peripheral injection patterns.

3. Regular injection patterns.

4. Cristal and basal injection patterns.

A wide variety of injection-production well arrangements have been used in injection projects. The most common patterns, as shown in Fig. 6, are the following (Ahme 2018):

- Direct line drive.

- Staggered line drive.

- Five spots.

- Seven spots.

- Nine spots.

In terms of cumulative oil production, Eq. 1 can be written as:

$\mathrm{NP}=\mathrm{NS}$ ED EA EV

Applying the above methods for this field, it has been found that totally four different well groups including 5 spots, 7 spots and 9 spots can be optimized (Fig. 7). In these cases, liquid rate is the last point of time; injection rate is fitting rate is $94 \%$. 

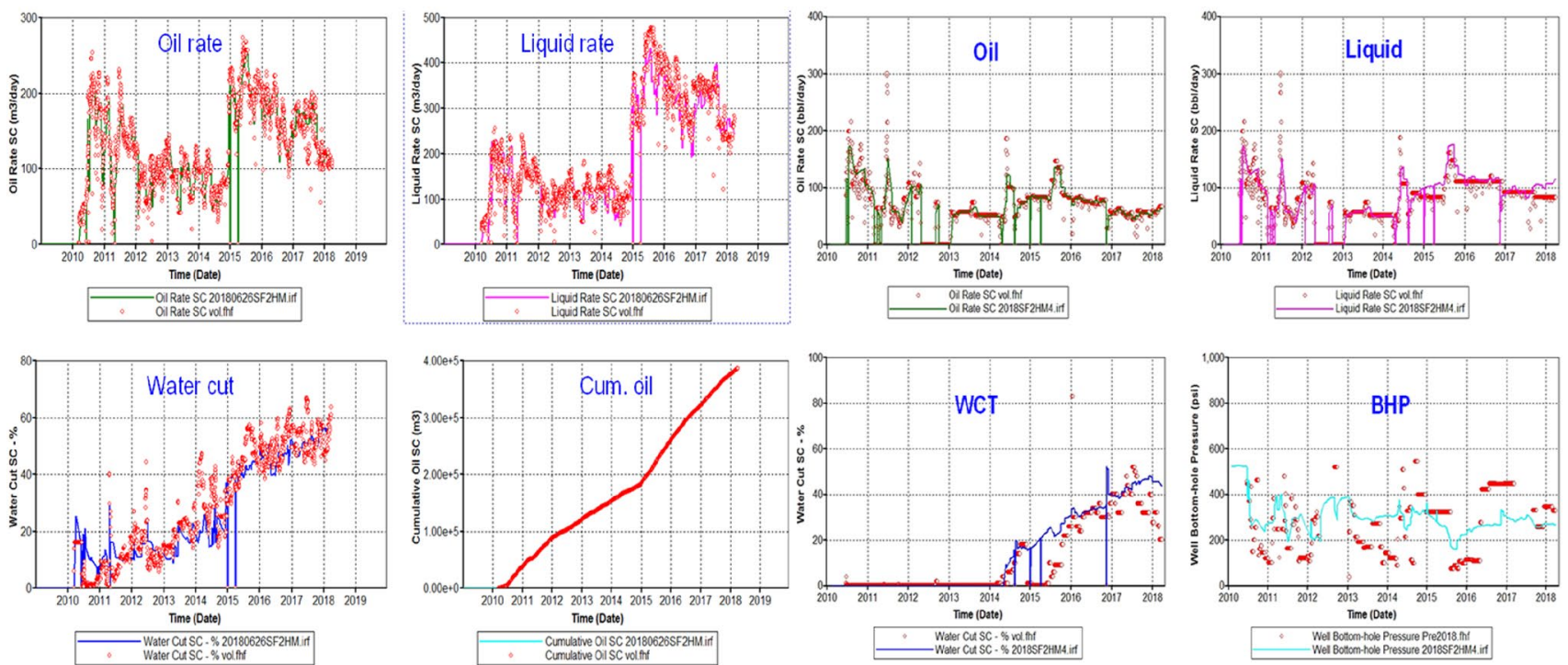

Fig. 5 History matching result of block and single well

Fig. 6 Flood patterns (Ahme 2018)
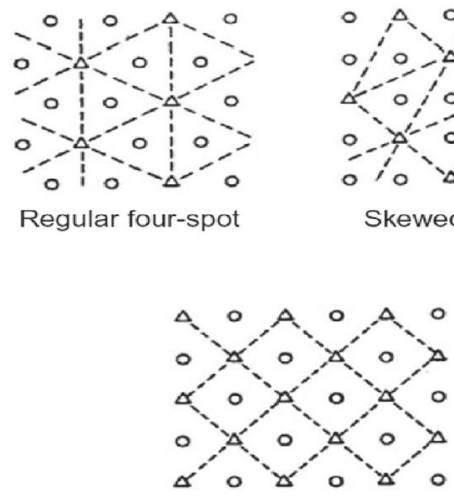

Five-spot

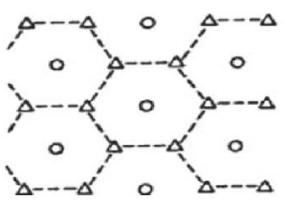

Seven-spot

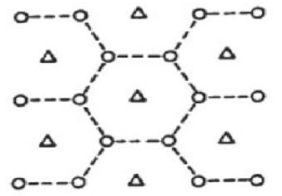

Inverted seven-spot

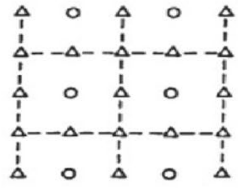

Normal nine-spot

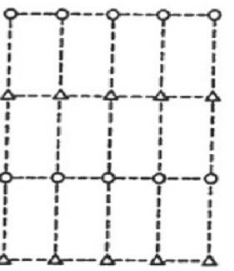

Direct line drive

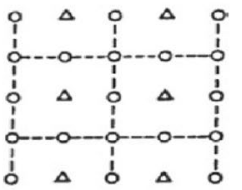

Inverted nine-spot

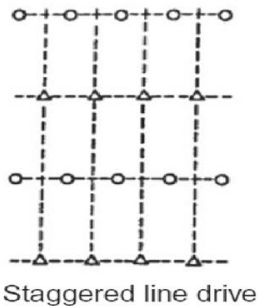

$100 \mathrm{~m}^{3} /$ day. For the forecast result, taking the new wells needed and economic condition into account, option 3 (7 spots) including 6 new producers is recommended in this case (Table 3 ).

\section{Optimization}

The optimization is done for the injection parameters such as injection rate, injection volume, injection pressure and temperature, also for the timing of converting from CSS to steam flooding besides the production parameters as well.

\section{Timing of converting to steam flooding}

There are four cases designed in order to know the timing of converting to steam flooding in this pilot area, including converting in January 2020, January 2021, January 2022 and January 2023. For the forecast result of these four cases, the oil recovery factor decreases along with the converted timing delay (Table 4, Fig. 8). Based on the temperature distribution in 2020 and 2021, the heat connectivity is already formed and most of the wells are in the fourth cycle until January 2020. According to experience of SF\#1 block, 
Fig. 7 Steam flooding well group options
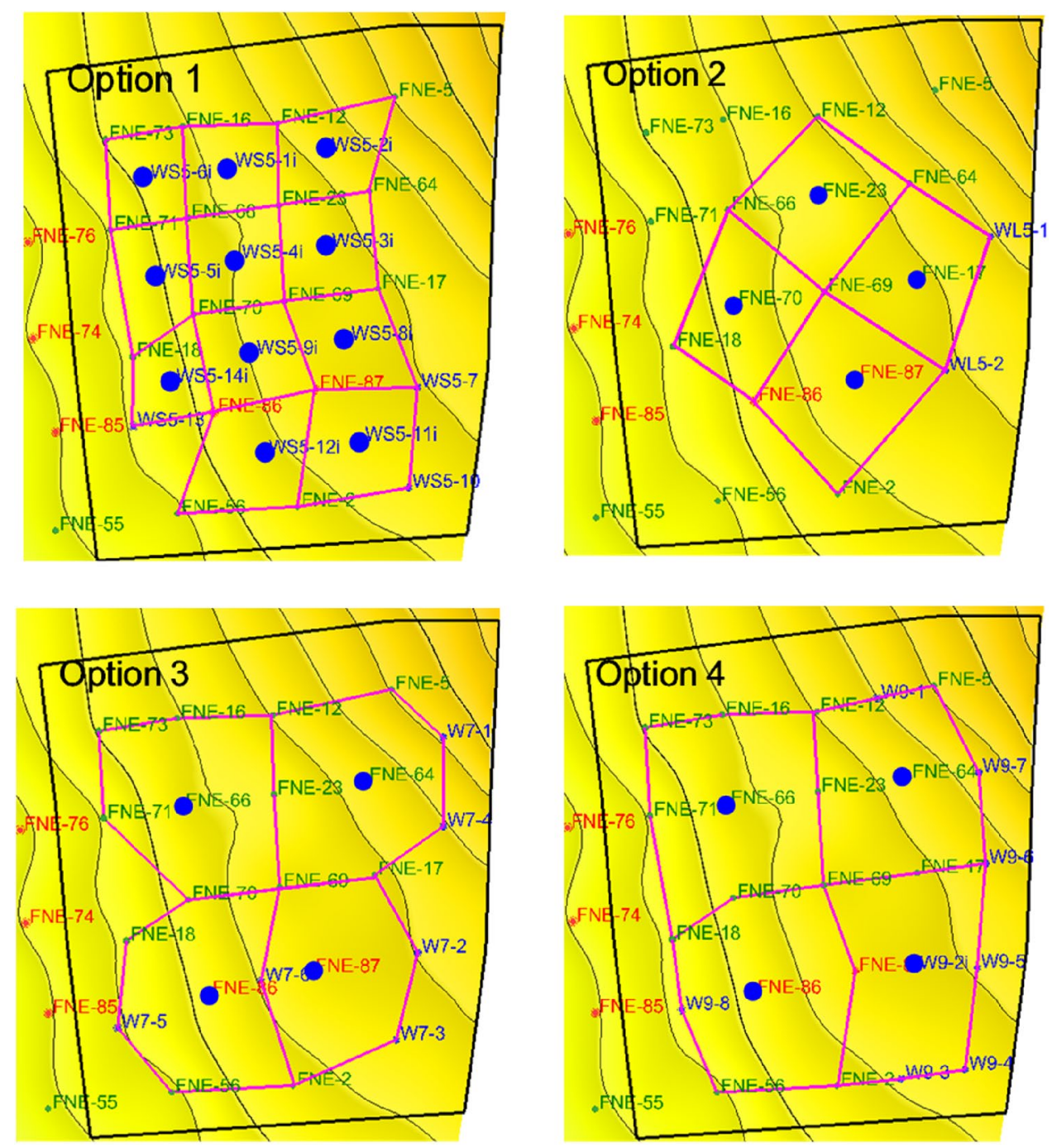

Table 3 SF designed and forecast result of each option

\begin{tabular}{|c|c|c|c|c|c|c|c|}
\hline No. & Well pattern & Injection timing & New well & Cum. oil (MMstb) & WIT $\left(\mathrm{MMm}^{3}\right)$ & $\mathrm{RF}(\%)$ & Comment \\
\hline 1 & 5 & 2018.10 & 14 & 8.23 & 3.54 & 27.6 & 11 new injectors, 3 new producers \\
\hline 2 & 5 & 2018.10 & 2 & 7.18 & 2.67 & 23.9 & $\begin{array}{l}4 \text { producer well convert to injector, } \\
2 \text { new producers }\end{array}$ \\
\hline 3 & 7 & 2018.10 & 6 & 8.18 & 2.59 & 27.3 & $\begin{array}{l}4 \text { producer well convert to injector, } \\
6 \text { new producers }\end{array}$ \\
\hline 4 & 9 & 2018.10 & 8 & 8.57 & 2.59 & 28.6 & $\begin{array}{l}3 \text { producer well convert to injector, } \\
1 \text { new injector, } 7 \text { new producers }\end{array}$ \\
\hline
\end{tabular}

SF\#2 pilot area could be converted for steam flooding in January 2020.

\section{Liquid rate and injection rate}

In this case, the producers' product intensity is $5-40 \mathrm{bbl} /$ day $m$ according to the production history of each well and the injector's injection index is $20-70 \mathrm{bbl} / \mathrm{day} \mathrm{m}$ same as
SF\#1 (Tables 5, 6). Based on reasonable liquid-steam ratio which ranges from 0.8 to 2.0 , ten cases are selected for optimization (Table 7).

For the forecast result of these ten cases, the oil recovery factor is increasing progressively along with the injection rate increasing (Table 8 ). Boiler condition is as follows: Steam outlet temperature is $300{ }^{\circ} \mathrm{C}$, boiler efficiency is $88 \%$, and if not considered the heat loss, the enthalpy of oil 
Table 4 Forecast index of converting to SF timing cases

\begin{tabular}{lllll}
\hline Item & Case 1 & Case 2 & Case 3 & Case 4 \\
\hline Converted timing & $2020 / 01$ & $2021 / 01$ & $2022 / 01$ & $2023 / 01$ \\
Ave. cycle & 5 & 6 & 7 & 8 \\
Cum. liquid (MMB) & 21.93 & 21.34 & 20.74 & 20.12 \\
Cum. oil (MMB) & 8.26 & 8.14 & 8.03 & 7.91 \\
Cum. injection $\left(\mathrm{MMm}^{3}\right)$ & 2.46 & 2.33 & 2.22 & 2.10 \\
Water cut (\%) & 79.34 & 79.53 & 79.44 & 77.68 \\
RF, Bentiu (\%) & 27.80 & 27.36 & 26.97 & 26.57 \\
\hline
\end{tabular}

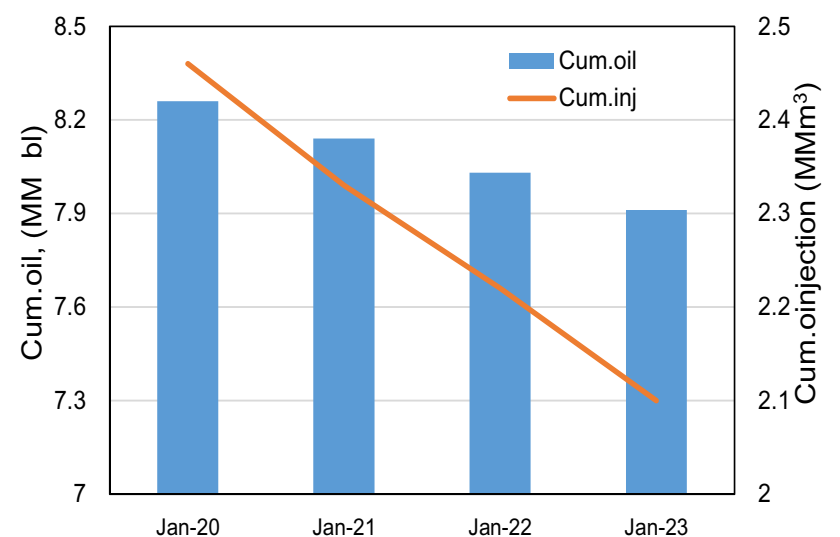

Fig. 8 Cumulative oil and injection steam along with injection timing delay

Table 5 Summary of product intensity for producers

\begin{tabular}{llllll}
\hline Well & \multirow{2}{*}{$\begin{array}{l}\text { Net pay } \\
\end{array}$} & $\mathrm{m}$ & \multicolumn{2}{l}{ Liquid rate of history } & $\begin{array}{l}\text { Product } \\
\text { intensity }\end{array}$ \\
\cline { 3 - 5 } & & $\begin{array}{l}\text { Min (bbl/ } \\
\text { day) }\end{array}$ & $\begin{array}{l}\text { Max (bbl/ } \\
\text { day) }\end{array}$ & bbl/day m & \\
\hline FNE-2 & 14 & 87 & 158 & 6.4 & 11.5 \\
FNE-5 & 14 & 58 & 300 & 4.1 & 21.1 \\
FNE-12 & 15 & 55 & 195 & 3.7 & 13.2 \\
FNE-16 & 17 & 58 & 600 & 3.4 & 35.1 \\
FNE-17 & 17 & 68 & 670 & 4.1 & 40.3 \\
FNE-18 & 15 & 74 & 586 & 5.0 & 39.4 \\
FNE-23 & 10 & 63 & 344 & 6.2 & 34.0 \\
FNE-56 & 11 & 52 & 470 & 4.7 & 42.7 \\
FNE-69 & 23 & 97 & 475 & 4.3 & 20.9 \\
FNE-70 & 12 & 160 & 360 & 13.3 & 30.0 \\
FNE-71 & 10 & 165 & 285 & 16.5 & 28.5 \\
FNE-73 & 12 & 75 & 350 & 6.2 & 29.0 \\
\hline
\end{tabular}

is $41900 \mathrm{~kJ} / \mathrm{kg}$. Enthalpy of saturated steam under $300{ }^{\circ} \mathrm{C}$ is $2750 \mathrm{~kJ} / \mathrm{kg}$, which means 0.5 barrel oil exchanges $1 \mathrm{~m}^{3}$ steam. For example, compared with case 6 , case 10 needs to spend $0.65 \mathrm{MMB}$ oil to get $1.3 \mathrm{MMm}^{3}$ steam. Considering the economic problem (water cut $98 \%$ ), case 10 needs to get net oil at least $0.276 \mathrm{MMbbl}$. So it needs to add oil
Table 6 Summary of injection index for injectors of SF\#1

\begin{tabular}{llllll}
\hline Well & Net pay & \multicolumn{2}{l}{ Liquid rate of history } & $\begin{array}{l}\text { Injection } \\
\text { intensity }\end{array}$ \\
\cline { 3 - 5 } & $\mathrm{m}$ & $\begin{array}{l}\text { Min } \\
\text { (bbl/day) }\end{array}$ & $\begin{array}{l}\text { Max } \\
\text { (bbl/day) }\end{array}$ & bbl/(day m) & \\
\hline FNE-50 & 21 & 445 & 742 & 21.2 & 35.3 \\
FNE-51 & 16 & 490 & 819 & 30.6 & 51.2 \\
FNE-52 & 16 & 387 & 900 & 24.2 & 56.3 \\
FNE-53 & 15 & 379 & 1024 & 25.3 & 68.3 \\
\hline
\end{tabular}

0.926 MMstb totally; however, it only needs to add oil 0.73 MMbbl (Table 9).

In conclusion, the liquid rate and injection rate of case 6 are chosen, producers' product intensity is $20 \mathrm{bbl} . /$ day $\mathrm{m}$ per well, steam injection index is $7 \mathrm{~m}^{3} /$ day $\mathrm{m}$ per well, and the average injection rate is $96 \mathrm{~m}^{3} /$ day per well.

\section{Steam quality and steam temperature}

There are totally 18 cases in this case, and the steam quality of injectors ranges from 0.6 to 0.9 and temperature ranges from 200 to $340{ }^{\circ} \mathrm{C}$ (Table 10). According to the forecast result, recovery factor of each case is different, but the difference is very small (Table 11). Taking the rationality of steam temperature and quality into consideration, the current case (case 8) is chosen although the recovery factor of case 12 is the highest.

\section{SG intermittent open}

There are totally 18 cases in this case, and the SG stop time ranges from 1 to 4 weeks and SG open time ranges from 1 to 6 weeks (Table 12). According to the forecast result, recovery factor of case 15 (open 6 weeks and stop 1 week) is the highest, but the value of current case (no stop) is higher (Table 13). Finally, the current case (no stop) could be kept.

\section{Product layer and injection layer}

There are totally 15 cases in layer optimization case, and oil zones include B1a, B1b and upper B1c (Table 14). There 


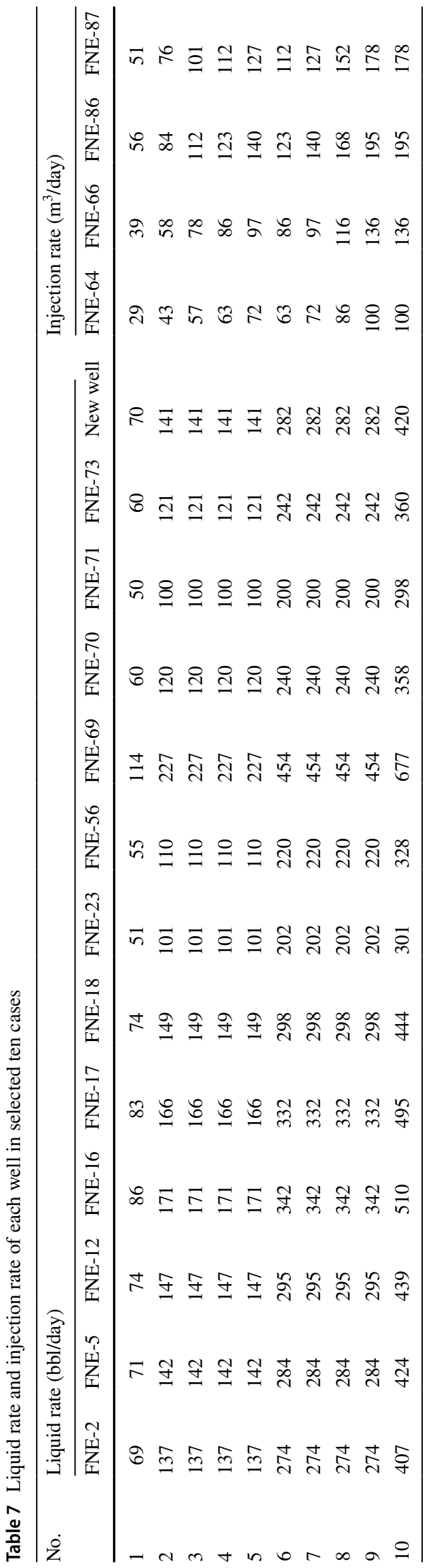

is no clear interbred between $\mathrm{B} 1 \mathrm{a}$ and $\mathrm{B} 1 \mathrm{~b}$ in the sector model also (Figs. 9, 10), and the wells grouping has been selected as shown in Fig. 11. The shale barrier has three types including clear shale barrier, thin shale barrier and no clear shale barrier after checking the logging interpretation result (Figs. 12, 13, 14). So case 12 was designed to simulate this situation, in which wells' perforation has three types (Table 15). Wells with clear shale barrier perforate B1a and B 1b. Wells with thin shale barrier perforate B 1a and upper B1b. Wells with no clear shale barrier perforate B1a. Some wells need to adjust perforation based on actual production situation such as FNE-5 and FNE-73.

According to the forecast result, the recovery factor of case 12 is the highest, $1 \%$ enhanced by the case with current perforation (Fig. 15). Case 12 for the shale barrier is recommended.

\section{Converting time from CSS to SF}

There are many reasons to convert CSS to SF such as changes in the temperature, pressure, and saturation of the well group, and from the previous study for this field and from numerical simulation results for turning to steam flooding and after comparing recovery percent of reservoirs, switching to steam flooding after the second period of steam stimulation is also the best (Elbaloula et al. 2016).

Considering the previous studies and experience of CSS implementation in FNE oil field, the assumption for the simulation was to start the SF as soon possible since most wells has more than two CSS cycles and many wells start production with CSS at different times.

\section{Final results}

Base on the above optimized result, FNE-03 block SF\#2 pilot area can choose 7 spots with 6 new producers and 4 wells converting to injectors in January 2020 (18producers +4 injectors). In the recommended case, the producers' production intensity and injectors' injection index are $20 \mathrm{bbl} /$ day $\mathrm{m}$ and $7 \mathrm{~m}^{3} /$ day $\mathrm{m}$, respectively (Tables 16,17 ). Steam quality and temperature need to maintain current situation of 0.7 and $270{ }^{\circ} \mathrm{C}$, respectively. The SG should not stop to inject steam, and considering shale barrier when adding new perforation is necessary.

For the recommended case forecast result, by the end of 2035 , cumulative oil is $9.69 \mathrm{MMbbl}$, oil recovery factor of Bentiu is $32.3 \%$ enhanced by $15 \%$ compared with do nothing case (Tables 18, 19 and Fig. 16). Compared the optimized oil rate and liquid rate in the recommended case with the actual current data (May. 2018), the production performance will be greatly improved. Also Aradaiba D formation can consider for future production and could get additional cumulative oil of 1.47 MMstb. 
Table 8 Liquid rate and injection rate of each well in selected ten cases

\begin{tabular}{|c|c|c|c|c|c|c|c|c|c|c|}
\hline Item/case & 1 & 2 & 3 & 4 & 5 & 6 & 7 & 8 & 9 & 10 \\
\hline Cum. liquid (MMB) & 12.0 & 19.4 & 19.4 & 19.4 & 19.5 & 33.7 & 33.7 & 33.9 & 34.0 & 47.5 \\
\hline Cum. oil (MMB) & 6.22 & 7.60 & 7.83 & 7.94 & 8.03 & 8.81 & 8.93 & 9.14 & 9.29 & 9.54 \\
\hline Cum. injection $\left(\mathrm{MMm}^{3}\right)$ & 1.14 & 1.65 & 2.14 & 2.37 & 2.67 & 2.37 & 2.67 & 3.17 & 3.67 & 3.67 \\
\hline RF, Bentiu (\%) & 20.91 & 25.55 & 26.32 & 26.70 & 27.00 & 29.63 & 30.05 & 30.77 & 31.27 & 32.12 \\
\hline OSR & 0.87 & 0.73 & 0.58 & 0.53 & 0.48 & 0.59 & 0.53 & 0.46 & 0.40 & 0.41 \\
\hline
\end{tabular}

Table 9 Liquid rate and injection rate of each well in selected ten cases

\begin{tabular}{lclcll}
\hline Item & Case 6 & Case 7 & Case 8 & Case 9 & Case 10 \\
\hline Cum. liquid (MMB) & 33.7 & 33.7 & 33.9 & 34 & 47.5 \\
Cum. oil (MMB) & 8.81 & 8.93 & 9.14 & 9.29 & 9.54 \\
Cum. injection (MMm3) & 2.37 & 2.67 & 3.17 & 3.67 & 3.67 \\
Add. inj. (MMm3) & & 0.3 & 0.8 & 1.3 & 1.3 \\
Fuel oil (MMB) & & 0.15 & 0.4 & 0.65 & 0.65 \\
Add. oil (MMB) & & 0.12 & 0.33 & 0.48 & 0.73 \\
Add. fluid (MMB) & 0 & 0.2 & 0.3 & 13.8 \\
98\% oil (MMB) & & 0 & 0.004 & 0.006 & 0.276 \\
Net oil (MMB) & & -0.03 & -0.074 & -0.176 & -0.196 \\
\hline
\end{tabular}

Table 10 Steam quality and seam temperature optimization cases

\begin{tabular}{lll}
\hline Case no. & Steam quality & Temperature \\
\hline 1 & 0.6 & 200 \\
2 & 0.6 & 230 \\
3 & 0.6 & 270 \\
4 & 0.6 & 300 \\
5 & 0.6 & 340 \\
6 & 0.7 & 200 \\
7 & 0.7 & 230 \\
8 & 0.7 & 270 \\
9 & 0.7 & 300 \\
10 & 0.7 & 340 \\
11 & 0.8 & 200 \\
12 & 0.8 & 250 \\
13 & 0.8 & 300 \\
14 & 0.8 & 340 \\
15 & 0.9 & 200 \\
16 & 0.9 & 250 \\
17 & 0.9 & 300 \\
18 & 0.9 & 340 \\
\hline
\end{tabular}

Table 12 SG open and stop times optimization cases

\begin{tabular}{lll}
\hline Case no. & $\begin{array}{l}\text { Injection time } \\
\text { Week }\end{array}$ & $\begin{array}{l}\text { Stop time } \\
\text { Week }\end{array}$ \\
\hline 1 & 1 & 1 \\
2 & 2 & 1 \\
3 & 2 & 2 \\
4 & 3 & 1 \\
5 & 3 & 2 \\
6 & 3 & 3 \\
7 & 4 & 1 \\
8 & 4 & 2 \\
9 & 4 & 3 \\
10 & 4 & 4 \\
11 & 5 & 1 \\
12 & 5 & 2 \\
13 & 5 & 3 \\
14 & 5 & 4 \\
15 & 6 & 1 \\
16 & 6 & 2 \\
17 & 6 & 3 \\
18 & 6 & 4 \\
\hline
\end{tabular}

Table 11 Forecast result of steam quality and steam temperature optimization cases

\begin{tabular}{|c|c|c|c|c|c|c|c|c|c|c|c|c|c|c|c|c|c|c|}
\hline Case & 1 & 2 & 3 & 4 & 5 & 6 & 7 & 8 & 9 & 10 & 11 & 12 & 13 & 14 & 15 & 16 & 17 & 18 \\
\hline Cum. liquid (MMB) & 33.6 & 33.6 & 33.6 & 33.6 & 33.6 & 33.6 & 33.6 & 33.6 & 33.6 & 33.6 & 33.6 & 33.6 & 33.6 & 33.6 & 33.6 & 33.6 & 33.6 & 33.6 \\
\hline Cum. oil (MMB) & 8.49 & 8.56 & 8.64 & 8.67 & 8.70 & 8.70 & 8.75 & 8.83 & 8.84 & 8.81 & 8.91 & 8.91 & 8.93 & 8.92 & 9.03 & 9.06 & 9.04 & 8.96 \\
\hline Cum. injection $\left(\mathrm{MMm}^{3}\right)$ & 2.37 & 2.37 & 2.37 & 2.37 & 2.37 & 2.37 & 2.37 & 2.37 & 2.37 & 2.37 & 2.37 & 2.37 & 2.37 & 2.37 & 2.37 & 2.37 & 2.37 & 2.37 \\
\hline RF, Bentiu (\%) & 28.7 & 28.9 & 29.2 & 29.3 & 29.4 & 29.4 & 29.6 & 29.8 & 29.9 & 29.8 & 30.1 & 30.1 & 30.2 & 30.1 & 30.5 & 30.6 & 30.6 & 30.3 \\
\hline
\end{tabular}


Table 13 Forecast result of SG open and stop time optimization cases

\begin{tabular}{lcccccccccccccccccccccc}
\hline Case & No stop & 1 & 2 & 3 & 4 & 5 & 6 & 7 & 8 & 9 & 10 & 11 & 12 & 13 & 14 & 15 & 16 & 17 & 18 \\
\hline Cum. liquid (MMB) & 33.6 & 32.3 & 32.9 & 32.2 & 33.1 & 32.6 & 32.2 & 33.2 & 32.9 & 32.5 & 32.2 & 33.3 & 33.0 & 32.7 & 32.5 & 33.3 & 33.1 & 32.9 & 32.6 \\
Cum. oil (MMB) & 8.83 & 7.94 & 8.23 & 7.96 & 8.36 & 8.16 & 8.01 & 8.44 & 8.26 & 8.13 & 8.01 & 8.49 & 8.32 & 8.23 & 8.14 & 8.55 & 8.37 & 8.27 & 8.20 \\
Cum. injection (MMm & ) & 2.37 & 1.19 & 1.54 & 1.19 & 1.72 & 1.4 & 1.19 & 1.82 & 1.54 & 1.34 & 1.19 & 1.89 & 1.64 & 1.45 & 1.31 & 1.95 & 1.71 & 1.54 & 1.40 \\
RF, Bentiu (\%) & 29.8 & 26.7 & 27.7 & 26.8 & 28.1 & 27.4 & 27.0 & 28.4 & 27.8 & 27.4 & 26.9 & 28.6 & 28.0 & 27.7 & 27.4 & 28.8 & 28.2 & 27.8 & 27.6 \\
\hline
\end{tabular}

Table 14 Product layer and injection layer optimization cases

\begin{tabular}{|c|c|c|}
\hline Case no. & Product layer & Injection layer \\
\hline 1 & $1 \mathrm{a}$ & $1 \mathrm{a}$ \\
\hline 2 & $1 \mathrm{~b}$ & $1 \mathrm{~b}$ \\
\hline 3 & $1 \mathrm{a} 1 \mathrm{~b}$ & $1 \mathrm{a} 1 \mathrm{~b}$ \\
\hline 4 & $1 \mathrm{a} 1 \mathrm{~b}$ & 1a \\
\hline 5 & $1 \mathrm{a} 1 \mathrm{~b}$ & $1 b$ \\
\hline 6 & $1 \mathrm{a} 1 \mathrm{~b} 1 \mathrm{c}$ & $1 \mathrm{a}$ \\
\hline 7 & $1 \mathrm{a} 1 \mathrm{~b} 1 \mathrm{c}$ & $1 \mathrm{~b}$ \\
\hline 8 & $1 \mathrm{a} 1 \mathrm{~b} 1 \mathrm{c}$ & $1 \mathrm{a} 1 \mathrm{~b} 1 \mathrm{c}$ \\
\hline 9 & $1 \mathrm{a} 1 \mathrm{~b}$ & $1 \mathrm{a} 1 \mathrm{~b} 1 \mathrm{c}$ \\
\hline 10 & $1 \mathrm{a} 1 \mathrm{c}$ & $1 \mathrm{a} 1 \mathrm{~b} 1 \mathrm{c}$ \\
\hline 11 & $1 \mathrm{~b} 1 \mathrm{c}$ & $1 \mathrm{a} 1 \mathrm{~b} 1 \mathrm{c}$ \\
\hline 12 & $1 \mathrm{a}, 1 \mathrm{a} \& 1 \mathrm{~b}$ and $1 \mathrm{a} \&$ upper $1 \mathrm{~b}$ & $1 \mathrm{a} \& 1 \mathrm{~b}$ and $1 \mathrm{a} \&$ upper $1 \mathrm{~b}$ \\
\hline 13 & $1 \mathrm{a} 1 \mathrm{~b} 1 \mathrm{c}$ & $1 \mathrm{a} 1 \mathrm{~b}$ \\
\hline 14 & $1 \mathrm{a} 1 \mathrm{~b} 1 \mathrm{c}$ & 1a $1 \mathrm{c}$ \\
\hline 15 & $1 \mathrm{a} 1 \mathrm{~b} 1 \mathrm{c}$ & $1 \mathrm{~b} 1 \mathrm{c}$ \\
\hline
\end{tabular}

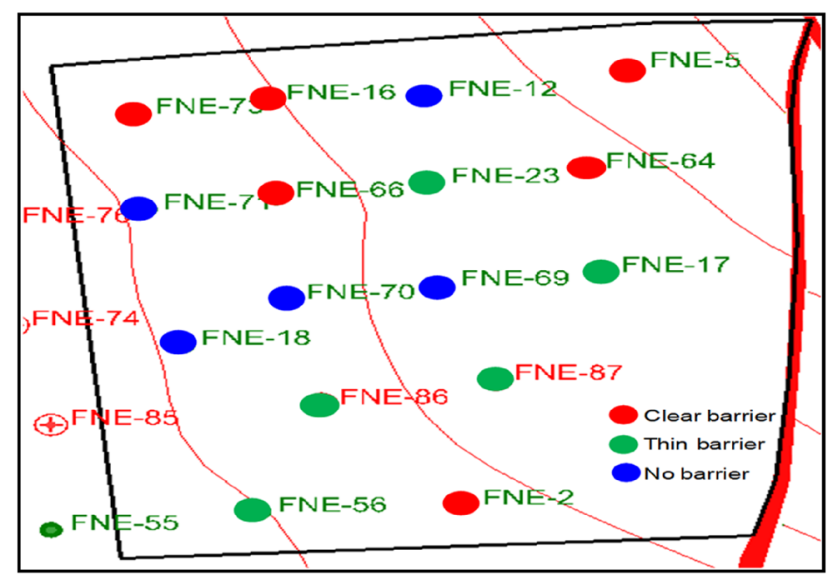

Fig. 9 Well type distribution

\section{Economic evaluation}

Although this work is a scenario-based optimization, simple economic evaluation model has been done for this research in order to fully picture the feasibility study of steam flooding in this area, and the assumptions for the sensitivity analysis are as follows:

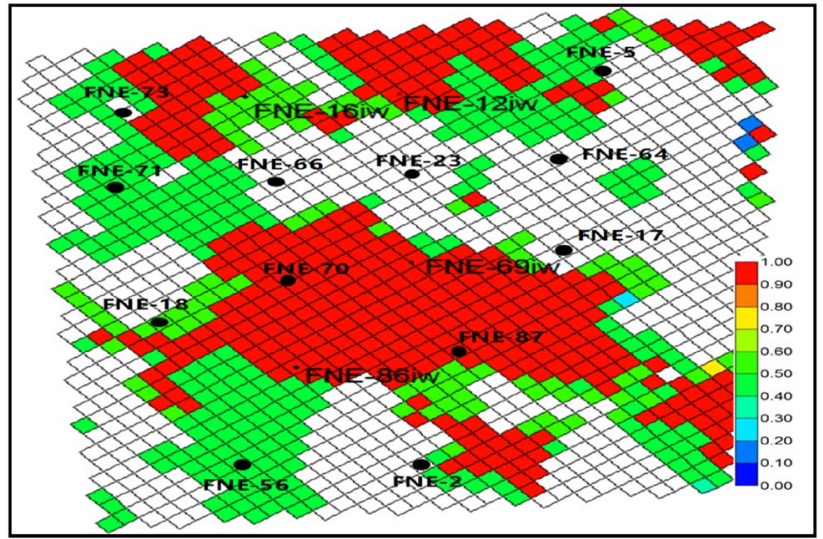

Fig. 10 Net gross of (B1a and B1b) layers

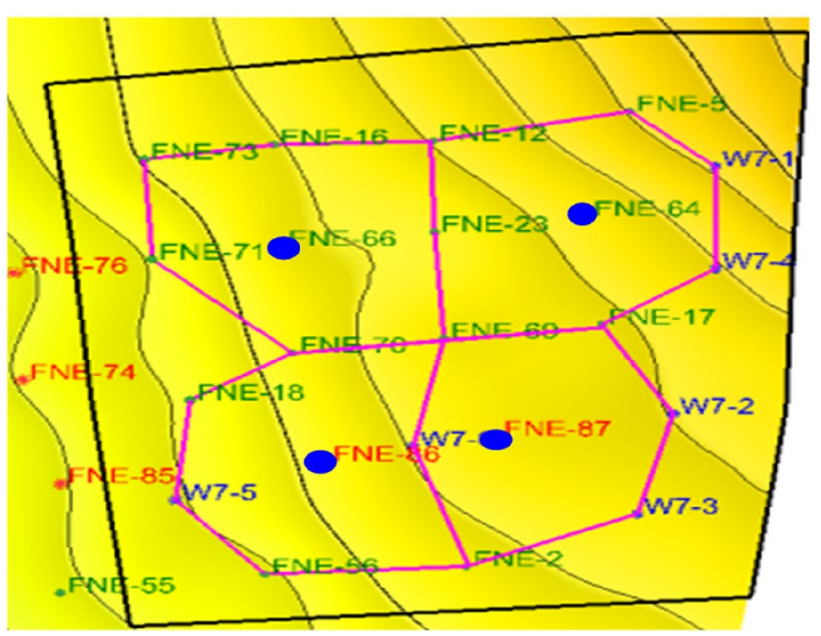

Fig. 11 Well group map

Evaluation period is 2016-2027, under the oil price of $50 \$ / \mathrm{bbl}$, we do the IRR sensitivity analysis of Contractor, and the variation scopes are $10 \%$ and $20 \%$, and the detailed sensitivity analysis results are given in Table 20 and Fig. 17.

From sensitivity analysis, the oil price is the most sensitive factor. When the oil price decreases $20 \%$, the IRR is $12.85 \%$ still greater than $10 \%$, which means the contractor has the strong ability to resist risks, and under the present oil price, the contractor is profit. 


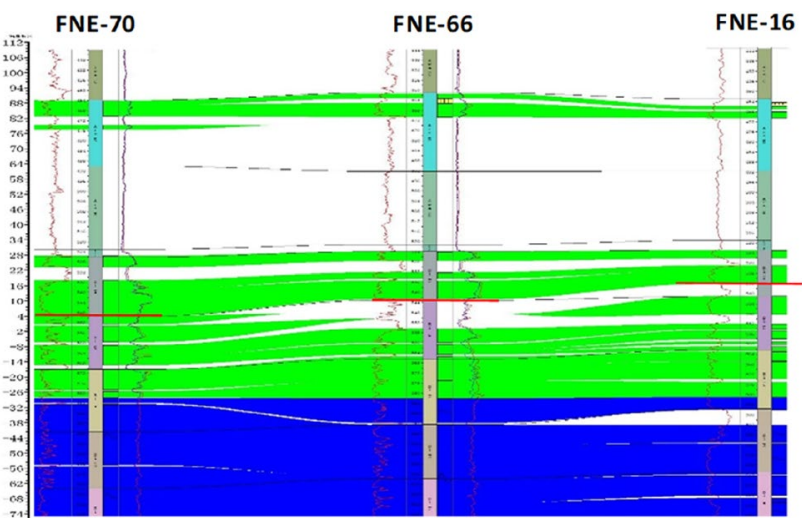

Fig. 12 Sand section around FNE-66

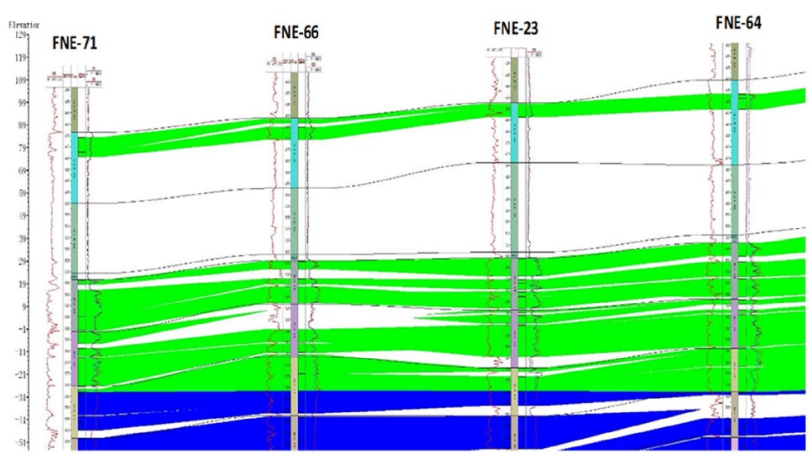

Fig. 13 Sand section around FNE-64 and FNE-66

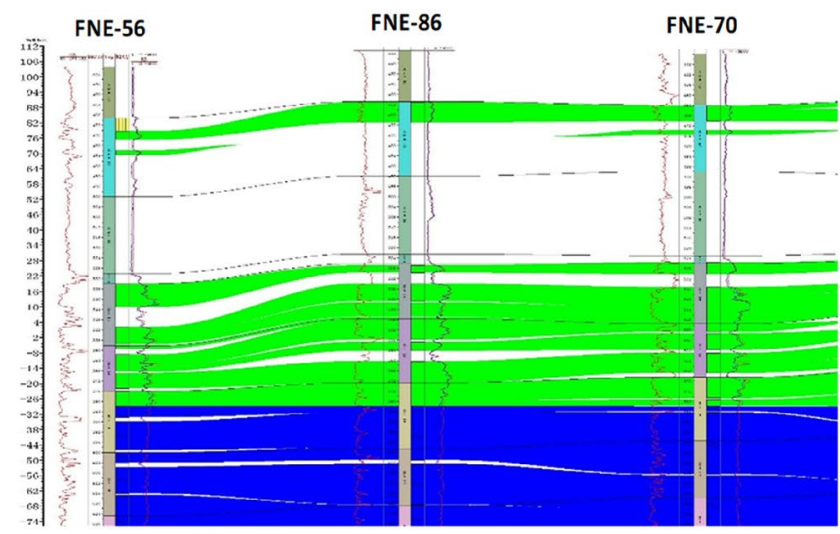

Also when the oil price is $40 \$ / \mathrm{bbl}$, the IRR of the four basic cases is $32.45 \%, 31.48 \%, 25.12 \%$ and $32.47 \%$. The state NPV of the four basic cases is $153.85 \mathrm{MM} \$, 208.29$ MM\$, 206.43 MM\$ and 212.46 MM\$, and in all of the cases except DNC case, from the sensitivity analysis, the oil price got the highest sensitivity of IRR, in the break-even point, the oil price is $34.78 \$ / \mathrm{bbl}$ of recommended case, all the cases are profit, but we still should pay more attentions to the international oil price to avoid investment risks.

\section{Conclusions and recommendation}

- The feasibility study to design the second steam flooding pilot test patterns in Sudanese oil field has been done, and the pilot area has been selected and designed using advanced thermal EOR simulator.

- After the analogy with the development effect of similar international oil fields, combined with international standards for thermal recovery, the preliminary result from the screening shows that FNE oil field is suitable for steam flooding.

- According to the geological and dynamic facts of FNE oil field, the steam flooding pilot test area and well groups have been selected in FNE-03 block SF\#2 pilot area and the optimized result to choose 7 spots with 6 new producers and 4 wells to be converted to injectors in 2020 .

- The results show that the optimum steam flooding parameters for this area are steam injection temperature of

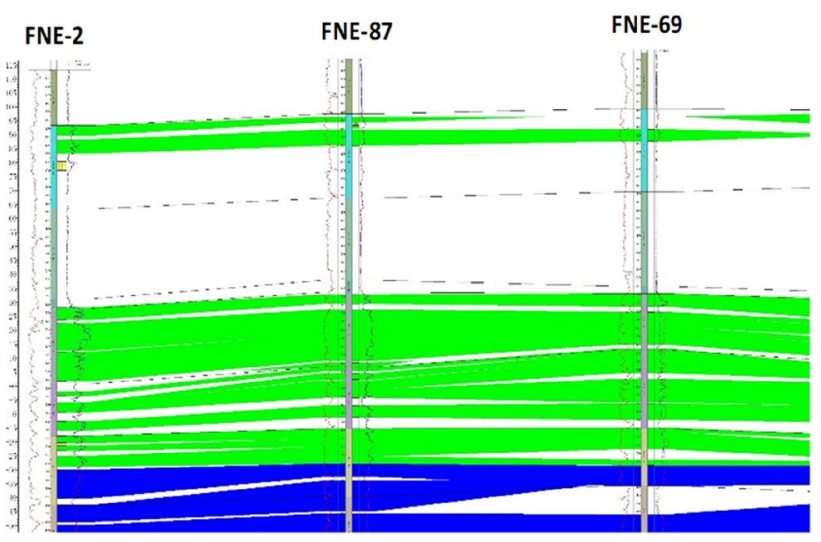

Fig. 14 Sand section around FNE-86 and FNE-87

Table 15 Perforation of each well in Case 12

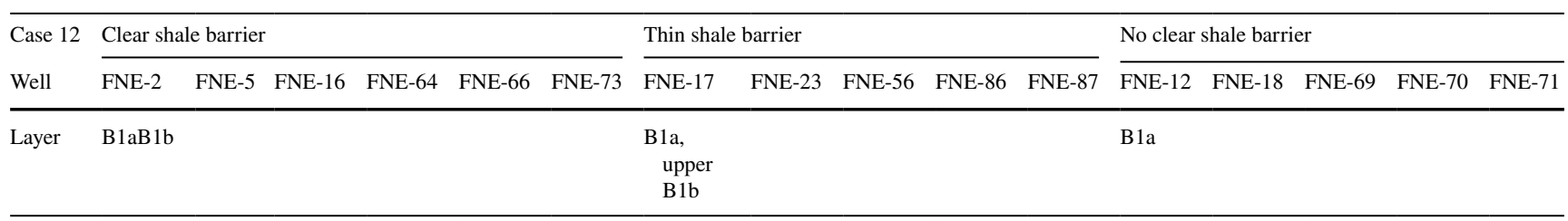



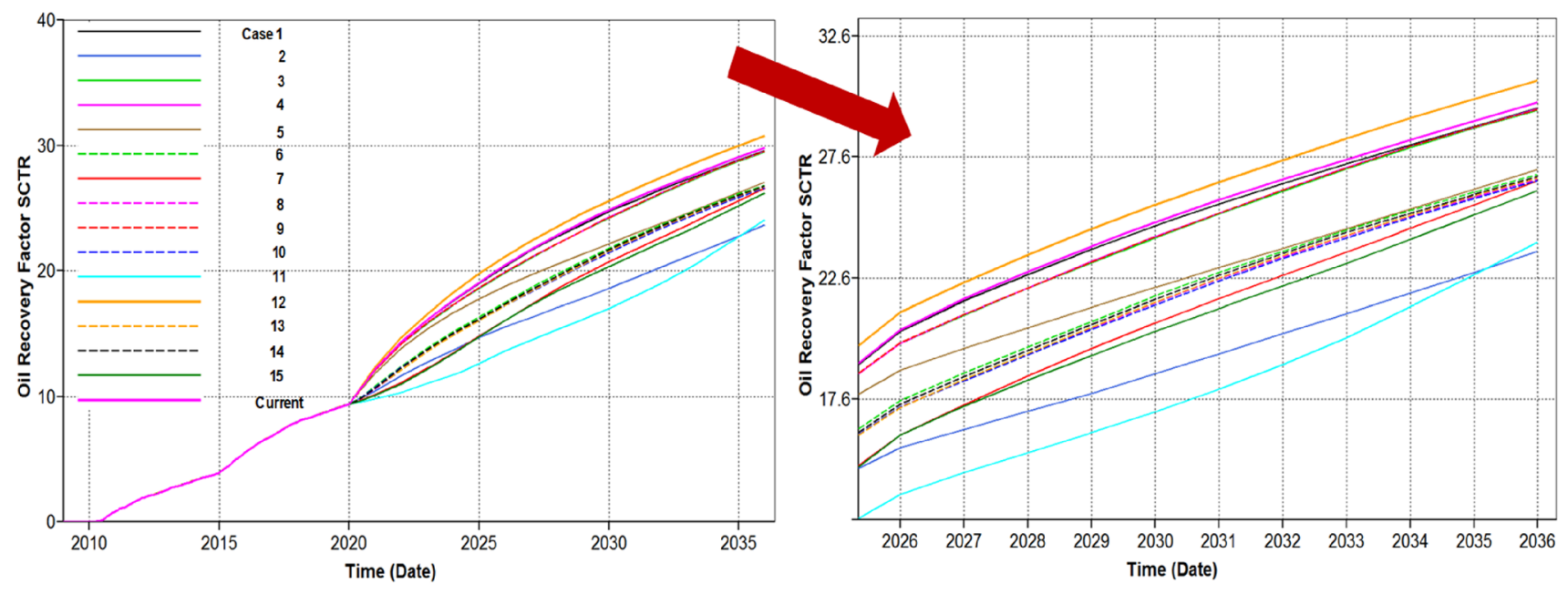

Fig. 15 Recovery factor curve of each case

Table 16 Liquid rate of producers in recommended case

\begin{tabular}{llllllllll}
\hline Well & FNE-2 & FNE-5 & FNE-12 & FNE-16 & FNE-17 & FNE-18 & FNE-23 & FNE-56 & FNE-69 \\
Interval & 523-548 & $503-528$ & $518.5-529$ & $523-562$ & $515.5-549$ & $536-553$ & $521-555$ & $538-568$ & $518.5-537$ \\
Layer & B1aB1b & B1a & B1a & B1aB1b & B1aB1b & B1a & B1aB1b & B1aB1b & B1a \\
Rate, bbl/day & 364 & 284 & 247 & 412 & 412 & 298 & 332 & 290 & 454 \\
Well & FNE-70 & FNE-71 & FNE-73 & W7-1 & W7-2 & W7-3 & W7-4 & W7-5 & W7-6 \\
Interval & $536-537$ & $539-549$ & $531-547$ & $504-546$ & $514-558$ & $518-562$ & $508.5-550.5$ & $534-559$ & $522.5-553$ \\
Layer & B1a & B1a & B1a & B1aB1b & B1aB1b & B1aB1b & B1aB1b & B1a & B1aB1b \\
Rate, bbl/day & 280 & 200 & 242 & 315 & 315 & 315 & 315 & 252 & 283 \\
\hline
\end{tabular}

Table 17 Injection rate of injectors in recommended case

\begin{tabular}{lllll}
\hline Well & FNE-64 & FNE-66 & FNE-86 & FNE-87 \\
Interval & $514-553$ & $524-566$ & $534.5-560$ & $524-555$ \\
Layer & B1aB1b & B1aB1b & B1aB1b & B1aB1b \\
Rate, $\mathrm{m}^{3}$ day & 87 & 98 & 148 & 143 \\
\hline
\end{tabular}

$270{ }^{\circ} \mathrm{C}$, with 5-7 MPa injection pressure, steam injection quality of more than 0.6 and steam injection rate of $1.6 \mathrm{~m}^{3} / \mathrm{day} / \mathrm{ha} / \mathrm{m}$, and the final recovery ratio will reach $32.3 \%$.
- The optimum production rate for producers is $20 \mathrm{bbl} /$ day $\mathrm{m}$ and for injectors' injection index is $7 \mathrm{~m}^{3} / \mathrm{day} \mathrm{m}$ ).

- From simple economic analysis, the IRR for the recommended case is $32.47 \%$, NPV is $212.46 \mathrm{MM} \$$, and in the break-even point, the oil price is $34.78 \$ / b b l$.

- It is highly recommended for this area to convert from CSS to steam flooding producing in 2020 in order to produce high recovery factor, and it is necessary to consider shale barrier when adding new perforation.

- It is strongly recommended to conduct detail economic evaluation for this area for field implementation.
Table 18 Forecast result of DNC and recommended case

\begin{tabular}{lllllll}
\hline Case & $\begin{array}{l}\text { Cum. liquid } \\
(\mathrm{MMB})\end{array}$ & $\begin{array}{l}\text { Cum. oil } \\
(\mathrm{MMB})\end{array}$ & $\begin{array}{l}\text { Cum. injection } \\
\left(\mathrm{MMm}^{3}\right)\end{array}$ & $\begin{array}{l}\text { Water cut } \\
(\%)\end{array}$ & $\begin{array}{l}\text { Production- } \\
\text { injection ratio }\end{array}$ & $\begin{array}{l}\text { RF (Bentiu) } \\
(\%)\end{array}$ \\
\hline DNC & 12.5 & 5.12 & 0.37 & 81.1 & 4.2 & 17.0 \\
$\begin{array}{l}\text { Recom- } \\
\text { mended } \\
\text { case }\end{array}$ & 36.8 & 9.69 & 2.90 & 89.0 & 2.0 & 32.3 \\
\hline
\end{tabular}


Table 19 Recommended case development indicator prediction

\begin{tabular}{|c|c|c|c|c|c|c|c|c|c|c|c|c|c|c|c|c|c|}
\hline \multirow{3}{*}{$\begin{array}{l}\text { Date } \\
\text { Year }\end{array}$} & \multirow[t]{3}{*}{ Oil well } & \multirow[t]{3}{*}{ Inj. well } & \multicolumn{3}{|c|}{ Pro. daily/effect well } & \multicolumn{3}{|c|}{ Pro. daily/all well } & \multicolumn{3}{|c|}{ Pro. yearly } & \multirow{3}{*}{$\begin{array}{l}\text { OSR } \\
\%\end{array}$} & \multicolumn{4}{|l|}{ Cum } & \multirow[t]{2}{*}{$\mathrm{RF}$} \\
\hline & & & Oil & Liquid & steam & Oil & Liquid & steam & Oil & Liquid & steam & & Oil & Water & Liquid & steam & \\
\hline & & & \multicolumn{3}{|c|}{ STB } & \multicolumn{3}{|l|}{ STB } & \multicolumn{3}{|c|}{ MMSTB } & & \multicolumn{4}{|c|}{ MMSTB } & $\%$ \\
\hline 2010 & 5 & & 152 & 160 & 25 & 762 & 799 & 75 & 0.01 & 0.26 & 0.03 & 0.2 & 0.24 & 0.02 & 0.26 & 0.03 & 0.8 \\
\hline 2011 & 5 & & 163 & 174 & 10 & 817 & 872 & 30 & 0.31 & 0.34 & 0.01 & 28.5 & 0.55 & 0.03 & 0.60 & 0.04 & 1.8 \\
\hline 2012 & 5 & & 151 & 163 & 10 & 754 & 815 & 29 & 0.21 & 0.23 & 0.01 & 19.2 & 0.75 & 0.02 & 0.83 & 0.05 & 2.5 \\
\hline 013 & 5 & & 128 & 151 & 33 & 640 & 753 & 100 & 0.21 & 0.24 & 0.04 & 5.7 & 0.96 & 0.03 & 1.07 & 0.09 & 3.2 \\
\hline 2014 & 9 & & 154 & 238 & 38 & 1384 & 2146 & 265 & 0.19 & 0.24 & 0.10 & 2.0 & 1.16 & 0.05 & 1.31 & 0.18 & 3.9 \\
\hline 2015 & 16 & & 74 & 129 & 15 & 1179 & 2061 & 205 & 0.48 & 0.75 & 0.07 & 6.4 & 1.63 & 0.28 & 2.06 & 0.26 & 5.5 \\
\hline 2016 & 16 & & 55 & 109 & 30 & 880 & 1752 & 423 & 0.38 & 0.67 & 0.15 & 2.5 & 2.02 & 0.29 & 2.73 & 0.41 & 6.7 \\
\hline 2017 & 16 & & 44 & 99 & 7 & 703 & 1578 & 103 & 0.36 & 0.71 & 0.04 & 9.4 & 2.37 & 0.35 & 3.44 & 0.45 & 7.9 \\
\hline 2018 & 16 & & 46 & 107 & 29 & 744 & 1711 & 401 & 0.25 & 0.54 & 0.15 & 1.7 & 2.61 & 0.29 & 3.94 & 0.60 & 8.6 \\
\hline 2019 & 16 & & 33 & 81 & 32 & 528 & 1289 & 442 & 0.23 & 0.53 & 0.16 & 1.4 & 2.82 & 0.30 & 4.41 & 0.76 & 9.3 \\
\hline 2020 & 18 & 4 & 130 & 295 & 750 & 2336 & 5303 & 3000 & 1.00 & 1.93 & 1.09 & 0.9 & 3.84 & 0.93 & 6.36 & 1.85 & 12.7 \\
\hline 2021 & 18 & 4 & 101 & 300 & 750 & 1823 & 5407 & 3000 & 0.76 & 1.97 & 1.09 & 0.7 & 4.60 & 1.21 & 8.32 & 2.95 & 15.3 \\
\hline 2022 & 18 & 4 & 84 & 301 & 750 & 1508 & 5427 & 3000 & 0.60 & 1.98 & 1.09 & 0.5 & 5.20 & 1.38 & 10.30 & 4.04 & 17.3 \\
\hline 2023 & 18 & 4 & 80 & 310 & 750 & 1443 & 5585 & 3000 & 0.54 & 2.03 & 1.09 & 0.5 & 5.74 & 1.47 & 12.30 & 5.13 & 19.1 \\
\hline 2024 & 18 & 4 & 70 & 310 & 750 & 1258 & 5585 & 3000 & 0.50 & 2.04 & 1.09 & 0.5 & 6.24 & 1.55 & 14.35 & 6.23 & 20.8 \\
\hline 2025 & 18 & 4 & 64 & 310 & 750 & 1157 & 5585 & 3000 & 0.44 & 2.04 & 1.09 & 0.4 & 6.68 & 1.60 & 16.39 & 7.32 & 22.2 \\
\hline 2026 & 18 & 4 & 58 & 310 & 750 & 1036 & 5585 & 3000 & 0.40 & 2.04 & 1.09 & 0.4 & 7.09 & 1.64 & 18.43 & 8.41 & 23.6 \\
\hline 2027 & 18 & 4 & 54 & 310 & 750 & 968 & 5585 & 3000 & 0.36 & 2.04 & 1.09 & 0.3 & 7.46 & 1.68 & 20.48 & 9.51 & 24.8 \\
\hline 2028 & 18 & 4 & 52 & 310 & 750 & 931 & 5585 & 3000 & 0.34 & 2.04 & 1.09 & 0.3 & 7.80 & 1.70 & 22.52 & 10.60 & 26.0 \\
\hline 2029 & 18 & 4 & 48 & 310 & 750 & 863 & 5585 & 3000 & 0.32 & 2.04 & 1.09 & 0.3 & 8.12 & 1.72 & 24.57 & 11.69 & 27.0 \\
\hline 2030 & 18 & 4 & 45 & 310 & 750 & 810 & 5585 & 3000 & 0.30 & 2.04 & 1.09 & 0.3 & 8.42 & 1.74 & 26.61 & 12.79 & 28.0 \\
\hline 2031 & 18 & 4 & 41 & 310 & 750 & 735 & 5585 & 3000 & 0.28 & 2.04 & 1.09 & 0.3 & 8.71 & 1.76 & 28.65 & 13.88 & 29.0 \\
\hline 2032 & 18 & 4 & 40 & 310 & 750 & 714 & 5585 & 3000 & 0.27 & 2.04 & 1.09 & 0.2 & 8.97 & 1.78 & 30.70 & 14.98 & 29.9 \\
\hline 2033 & 18 & 4 & 36 & 310 & 750 & 654 & 5585 & 3000 & 0.25 & 2.04 & 1.09 & 0.2 & 9.22 & 1.79 & 32.75 & 16.07 & 30.7 \\
\hline 2034 & 18 & 4 & 35 & 310 & 750 & 630 & 5585 & 3000 & 0.24 & 2.04 & 1.09 & 0.2 & 9.46 & 1.81 & 34.79 & 17.16 & 31.5 \\
\hline 2035 & 18 & 4 & 34 & 310 & 750 & 607 & 5585 & 3000 & 0.23 & 2.04 & 1.09 & 0.2 & 9.68 & 1.81 & 36.83 & 18.25 & 32.3 \\
\hline
\end{tabular}
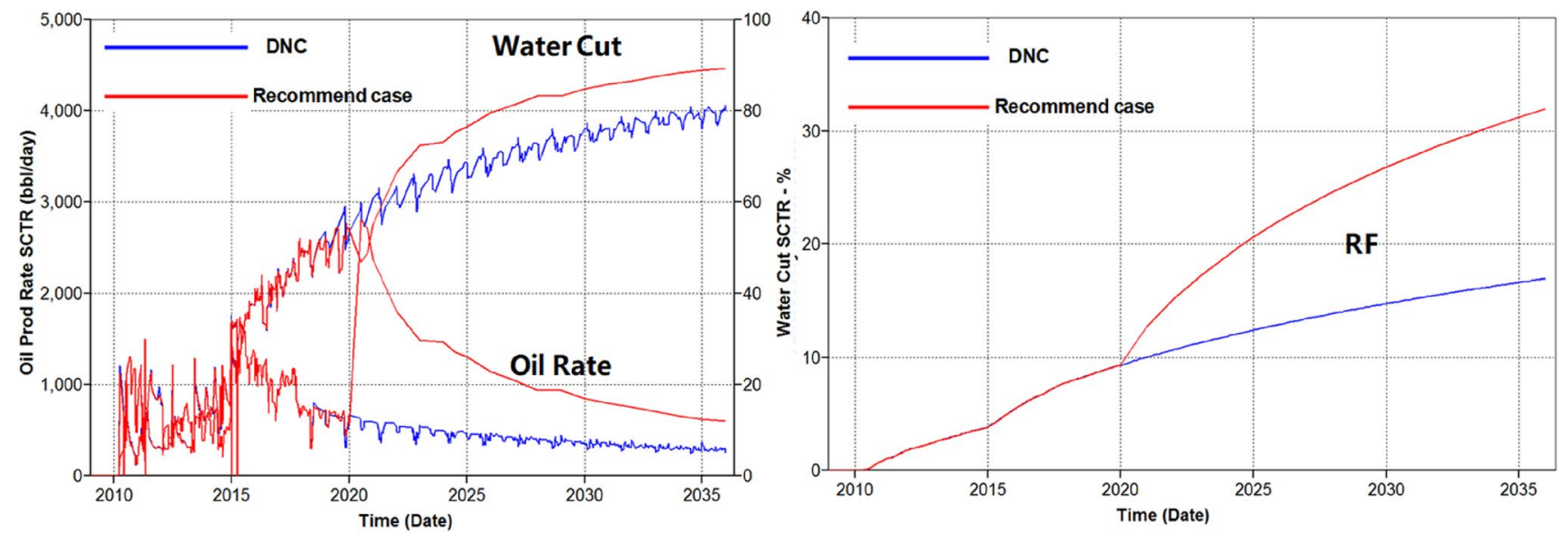

Fig. 16 Oil rate, water cut and recovery factor curve of recommended case 
Table 20 The net cash flow for the contractor $(50 \$ / b b l)$

\begin{tabular}{|c|c|c|c|c|c|c|c|c|c|c|c|c|}
\hline Time & 2016 & 2017 & 2018 & 2019 & 2020 & 2021 & 2022 & 2023 & 2024 & 2025 & 2026 & 2027 \\
\hline State net cash flow (US\$ MM) & -27.68 & -35.8 & -24.6 & -45.3 & 47.66 & 74.46 & 74.88 & 57.29 & 37.95 & 34.56 & 33.59 & 32.21 \\
\hline Time & 2028 & 2029 & 2030 & 2031 & 2032 & 2033 & 2034 & 2035 & & & & \\
\hline State net cash flow (US\$ MM) & 31.09 & 29.75 & 28.5 & 27.6 & 28.28 & 27.69 & 26.97 & 27.59 & & & & \\
\hline NPV (10\%) & $132.85 \mathrm{MM} \$$ & & & & & & & & & & & \\
\hline NPV (13\%) & 88.52 MM\$ & & & & & & & & & & & \\
\hline NPV $(15 \%)$ & $66.32 \mathrm{MM} \$$ & & & & & & & & & & & \\
\hline IRR & 26.45 & & & & & & & & & & & \\
\hline Recovery time (years) & 6.15 & & & & & & & & & & & \\
\hline
\end{tabular}

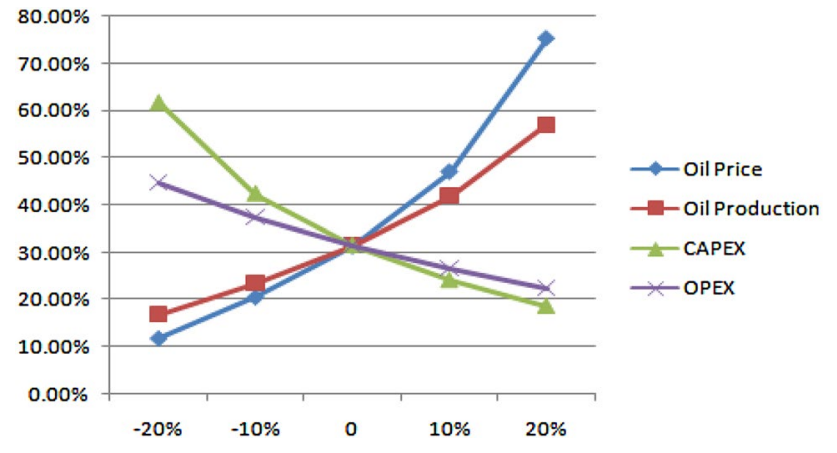

Fig. 17 IRR sensitivity analysis $(50 \$ / b b l)$

Acknowledgements The authors would like to thank Oil Exploration and Production Authority (OEPA), Ministry of Petroleum and Mining (MOPM) and Petro-energy E\&P Co. Ltd., for the permission to publish this paper.

\section{References}

Ahem T (2018) Reservoir engineering handbook, 5th edn. Gulf Professional Publishing, Cambridge, pp 209-210

Elbaloula HA (2017) Sudan University of Science and Technology, Petro-Energy-E\&P; Dr. Tagwa A. Musa Sudan University of Science and Technology. Full Field Implementation of Cyclic Steam Stimulation to Enhanced Oil Recovery for a Sudanese Oil Field"
International Conference on Industrial Engineering and Operations Management, Rabat, Morocco, April 11-13, 2017

Elbaloula H, Pengxiang H, Elammas T, Alwad F (2016) Petro-energy E\&P Co.Ltd, Mustafa A. Abdelmutalib, Mosab Fathelrahman, Sudanese Petroleum Corporation, Tagwa Ahmed Musa (Sudan University of Science and Technology) SPE Kingdom of Saudi Arabia Annual Technical Symposium and Exhibition "Designing and Implementation of the First Steam Flooding Pilot Test in Sudanese Oil Field and Africa". Society of Petroleum Engineering (SPE) April 25, 2016. Dammam -KSA, http://dx.doi. org/10.2118/182790-MS

Jiu-quan A, Li J, Jiang H (2006) Steam-flood trial and research on middeep heavy oil reservoir QI40 block in Liaohe oilfield. Society of Petroleum Engineers. https://doi.org/10.2118/104403-ms

Jones J, McWilliams M, Sturm D (1995) Kern river revisited: life after steam flood. Society of Petroleum Engineers. SPE Western Regional Meeting, 8-10 March, Bakersfield, California https:// doi.org/10.2118/29664-ms

Pearce JC, Megginson EA (1991) Current status of the Duri Steamflood Project Sumatra, Indonesia. Society of Petroleum Engineers, SPE International Thermal Operations Symposium, 7-8 February, Bakersfield, California. https://doi.org/10.2118/21527-ms

Prats M (1982) Thermal recovery, No. 7. Richardson, Texas: Monograph Series, SPE, USA

Taber JJ et al (1997) EOR screening criteria revisited-part 1: introduction to screening criteria and enhanced recovery field projects. SPE Reserv Eng J 12:189-198

Publisher's Note Springer Nature remains neutral with regard to jurisdictional claims in published maps and institutional affiliations. 